\title{
A comparison of methods for extracting plasmids from a difficult to lyse bacterium:
}

\section{Lactobacillus casei}

\author{
Mojtaba Alimolaei ${ }^{1,2}$, Mehdi Golchin $^{1 *}$
}

Running title: A comparison of methods for extracting plasmids from Lactobacillus casei

\begin{abstract}
Addresses:
${ }^{1}$ Department of Pathobiology, Faculty of Veterinary Medicine, Shahid Bahonar University of Kerman, Kerman, Iran

${ }^{2}$ Department of Molecular Microbiology, Kerman branch, Razi Vaccine and Serum Research Institute, Agricultural Research, Education and Extension Organization (AREEO), Kerman, Iran
\end{abstract}

*Corresponding author Mailing address: golchin@uk.ac.ir

Postal Code: 7616914111

Post Box: 76169-133, Kerman, Iran

Tel. \& Fax: +98- 343257447 
Keywords: Lactobacillus casei; Plasmid;Extraction; PCR 


\section{INTRODUCTION}

Bacteria belonging to the genus Lactobacillus are the members of lactic acid bacteria (LAB), a broadly defined group of the intestinal microflora [1]. These bacteria exist in the intestine of most animals and humans [2]. This phylogenetically diverse genus plays an important role in the food industry and has a significant potential as an oral vaccine delivery vehicle using the plasmids that expresses bioactive compounds at mucosal surfaces $[3,4]$.

The metabolism of lactose, fermentation of citrate, production of bacteriocin, proteinase activity and resistancy to phage or drugs are some of plasmid associated phenotypes in Lactobacillus. Also, some plasmids are traditionally used for genetic engineering in this genus [5-9].

Failure to demonstrate plasmids in $L$. casei could reveal ineffectiveness of the current protocols to extract efficient plasmid DNA from this bacterium [10]. The most important problem is the difficulty of cell lysis for extraction and purification of plasmids [10]. This is due to the huge exopolysaccharide coat of $L$. casei [11]. The important key in cloning molecular assays on $L$. casei is the extraction of efficient and purified plasmids. In the present investigation, different extraction methods were studied and an efficient protocol was optimized to extract plasmid DNA from a recombinant $L$. casei strain.

\section{Materials and methods}

Bacterial strains and growth conditions 
For precise control of the test, a previously constructed recombinant $L$. casei strain was used [12]. Briefly, epsilon toxin gene of Clostridium perfringens was synthesized by Generay Biotechnology Company (China) and cloned between BamHI and NaeI restriction sites of pT1NX vector obtained from BCCM/LMBP plasmid collection, University of Ghent, Belgium (http://bccm.belspo.be/about/lmbp.php). The modified vector was transformed into L. casei ATCC: 393 by a Gene Pulser ${ }^{\mathrm{TM}}$ apparatus (Bio-Rad Laboratories, Richmond, CA). This strain was anaerobically grown at $37^{\circ} \mathrm{C}$ for $24 \mathrm{~h}$ in deMan, Rogosa and Sharpe (MRS) medium (Himedia, India), supplemented with erythromycin ( $7.5 \mu \mathrm{g} / \mathrm{ml})$.

\section{Plasmid DNA extraction}

All the DNA manipulations were basically performed according to the standard procedures [13]. In this study, eleven plasmid extraction and purification protocols were tested in three classes: kit-based, conventional and combined protocols (Table 1).

\section{Kit-based protocols}

In this class, five protocols were performed (P1-P5). For all these protocols, after growing overnight cultures of $L$. casei at $37^{\circ} \mathrm{C}$, a volume of $4 \mathrm{ml}$ of each culture was centrifuged for 15 min at $13,000 \mathrm{rpm}(16,000 \times \mathrm{g})$ and $4^{\circ} \mathrm{C}$. This pellet was used for plasmid extraction in different protocols as described below.

The $P 1$ protocol was accurately performed based on PrimePrep ${ }^{\mathrm{TM}}$ plasmid DNA isolation kit (GeNet Bio, Korea) according to the manufacturer's instruction. The $P 2$ protocol was done similar to $P l$ with one modification: addition of lysozyme $(20 \mathrm{mg} / \mathrm{ml})$ to $P R$ buffer 
(PrimePrep $^{\mathrm{TM}}$ kit) for better lysis performance. In the $P 3$ protocol, the lysis step was carried out according to O'sullivan [9] and other steps were continued based on the kit protocol. In the last kit based protocols ( $P 4$ and $P 5)$, after preliminary centrifugation, the pellet was washed once with STE buffer ( $8 \%$ sucrose, 50 mMTris HCL, 1 mM EDTA, $\mathrm{pH}=8.0$ ) and then resuspended in $200 \mu \mathrm{L}$ of the same buffer containing lysozyme (20 $\mathrm{mg} / \mathrm{ml})$. The mixture was incubated for $1 \mathrm{~h}$ in the $P 4$ and $2 \mathrm{~h}$ in the $P 5$ protocol at $37^{\circ} \mathrm{C}$. Alkaline SDS lysis (3\% SDS, $0.2 \mathrm{~N} \mathrm{NaOH}$ ) was performed according to O'sullivan et al. (1993) and continued based on the kit protocol [9].

\section{Conventional protocols}

In the conventional category, four previously described protocols were performed with some modifications $[3,10,14]$. First, after growing the overnight culture of $L$. casei at $37^{\circ} \mathrm{C}$, a volume of $2 \mathrm{ml}$ of culture was inoculated in $10 \mathrm{ml}$ of the fresh MRS broth medium and then incubated at $37^{\circ} \mathrm{C}$ for two hours in the presence of $10 \% \mathrm{CO}_{2}$. Then, four milliliters of each culture were centrifuged for $5 \mathrm{~min}$ at $8000 \mathrm{rpm}(6,000 \times \mathrm{g})$ and $4^{\circ} \mathrm{C}$ and then, pellets were collected for extraction of plasmids in different protocols (P6-P9).

Both the $P 6$ and $P 7$ protocols were based on Klaenhammerwith some modifications [10]. In the lysis step of the $P 6$ protocol, the mixture was incubated at $37^{\circ} \mathrm{C}$ for $1 \mathrm{~h}$, whereas in the same step in the $P 7$ protocol, the mixture placed in an ice bath for one hour. After the completion of this step, deproteinization was performed with the addition of $50 \mu \mathrm{L}$ of $2 \mathrm{M}$ Tris $\mathrm{HCl}, \mathrm{pH}=7$, and $70 \mu \mathrm{L}$ of $5 \mathrm{M} \mathrm{NaCl}$ to each tube, which was then mixed gently and centrifuged at $13000 \mathrm{rpm}(16,000 \times \mathrm{g})$ for $10 \mathrm{~min}$. The supernatant was transferred to a new 
tube and the amount of $800 \mu \mathrm{L}$ of ice cold ethanol was added, mixed by inversion, and placed on ice for one hour. This mixture was centrifuged at $12000 \mathrm{rpm}(13,500 \times \mathrm{g})$ for 10 min and the collected pellet was washed with $500 \mu \mathrm{L}$ of $70 \%$ ethanol. The pellet was dried and dissolved in $100 \mu \mathrm{L}$ of TE buffer (50 mM Tris and $10 \mathrm{mM}$ EDTA, pH=7), and incubated at $65^{\circ} \mathrm{C}$ for $30 \mathrm{~min}$. At the end, preparations were incubated overnight at $4^{\circ} \mathrm{C}$ for solubilization of the extracted plasmids.

Two other conventional protocols ( $P 8$ and $P 9$ ) were based on Soomro et al. (2007) with few modifications as follows. In these protocols, we added $100 \mu \mathrm{L}$ of lysozyme $(40 \mathrm{mg} / \mathrm{ml})$ solution to suspended pellets and placed them on ice for $1 \mathrm{~h}$ and $2 \mathrm{~h}$ in the $P 8$ and $P 9$ protocols, respectively. Other steps of these protocols were similar to originated procedure [3].

\section{Combined protocols}

In this study, two combined protocols, namely $P 10$ and $P 11$, were designed. The $P 10$ protocol was a combination of the $P 9$ and $P 1$ protocols. Indeed, we performed $P 10$ as $P 9$ until the neutralization step and later steps were done according to the $P 1$ protocol. In the $P 11$ protocol, a combination of the $P 7$ and $P 1$ protocols was used. This protocol was carried out according to $P 7$ until the purification step and afterwards, it followed the $P 1$ procedure. 
Table 1: Different plasmid extraction and purification protocols from a recombinant $L$. casei tested in three classes of conventional, kit-based, and combined protocols

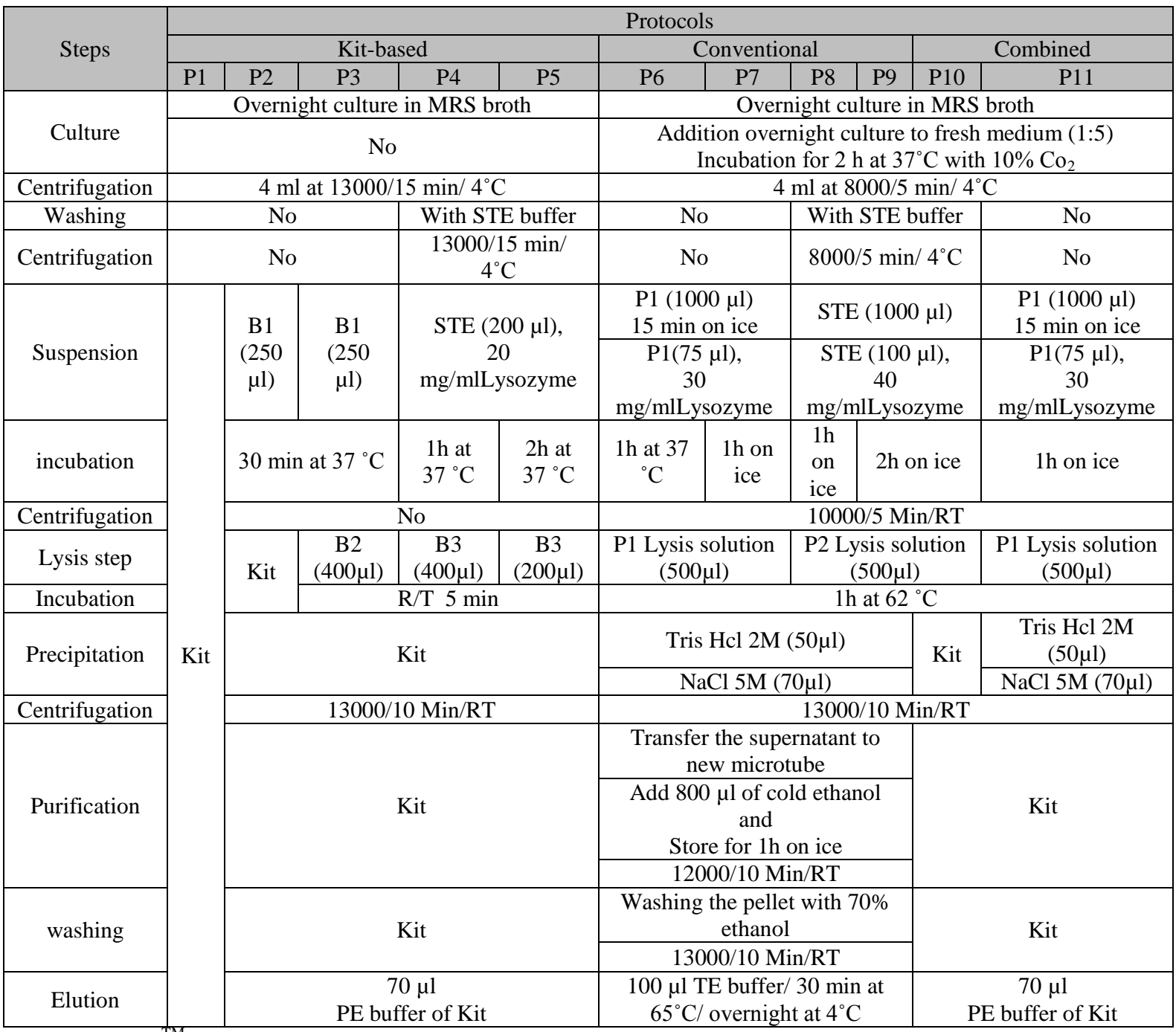

Kit: PrimePrep ${ }^{\mathrm{TM}}$ Plasmid DNA Isolation Kit (GeNet Bio, Korea)

STE buffer: $8 \%$ Sucrose, $50 \mathrm{mM}$ Tris HCL, 1 mM EDTA, $\mathrm{pH}=8.0$

PRL buffer: PR Buffer of Kit; $30 \mathrm{mg} / \mathrm{ml}$ Lysozyme

B1 buffer: $25 \%$ Sucrose; $30 \mathrm{mg} / \mathrm{ml}$ Lysozyme

P1 buffer: 25\% Sucrose; $50 \mathrm{mM}$ Tris, $\mathrm{pH}, 7.5$; 5 mM EDTA

B2 buffer: 3\% SDS; $0.2 \mathrm{~N} \mathrm{NaOH}$

B3 buffer: $1 \%$ SDS; $200 \mathrm{mM} \mathrm{NaOH}$

P1 Lysis Solution: $50 \mathrm{mM}$ Tris; $5 \mathrm{mM}$ EDTA; $50 \mathrm{mM}$ Glucose; 3\% SDS

P2 Lysis Solution: 50 mM Tris-HCl; 5 mM EDTA; 3\% SDS, pH, 12.35

PE buffer: $10 \mathrm{mM}$ Tris- $\mathrm{HCl}, \mathrm{pH} 8.5$

TE buffer: $10 \mathrm{mM}$ Tris-HCl; 1 mM EDTA, $\mathrm{pH}, 8.0$ 


\section{Evaluating the quantity and quality of the extracted plasmids}

The presence and integrity of the extracted plasmids were evaluated by agarose gel electrophoresis using the horizontal electrophoresis system (Bio-Rad). The types of band patterns indicate the quality of the extracted plasmids.

Moreover, the extracted plasmids were quantified by spectrophotometry using a BioPhotometer plus (Eppendorf, Germany) at 260 and $280 \mathrm{~nm}$. The quality of plasmid DNA was determined by $\mathrm{A}_{260} / \mathrm{A}_{280}$ ratio. The system software provided the DNA concentration $(\mathrm{ng} / \mu \mathrm{l})$ and automatically calculated the absorption ratio $\left(\mathrm{A}_{260} / \mathrm{A}_{280}\right)$. Further, total plasmid yield was calculated as described by Sambrook [13].

\section{PCR using extracted DNA}

In order to check the efficiency and applicability of the extracted plasmid DNA, each DNA was tested by PCR. The extracted plasmids were used as template for the selective amplification of cloned epsilon toxin gene (etx) of $C$. perfringens. The selected specific primers (Sinaclon, Iran) were forward 5'TGGGAACTTCGATACAAGCA3' and reverse 5'CCACTTACTTGTCCTACTAAC3'. Expected size of the amplified fragment corresponded to $238 \mathrm{bp}$.

PCR reaction was performed using $5 \mu \mathrm{l}$ of the extracted DNA with $25 \mu 1$ of ready-to-use PCR master mix 2x (Sinaclon, Iran), $2.5 \mu \mathrm{l}\left(20\right.$ pmole/ $\mu$ l) of each primer, and $\mathrm{dH}_{2} \mathrm{O}$ until $50 \mu \mathrm{l}$ volume. Amplicons of etx were obtained with 35 cycles following an initial denaturation step at $95^{\circ} \mathrm{C}$ for $10 \mathrm{~min}$. Each cycle involved denaturation at $94^{\circ} \mathrm{C}$ for $1 \mathrm{~min}$, annealing at $52.5^{\circ} \mathrm{C}$ for $1 \mathrm{~min}$, synthesis at $72^{\circ} \mathrm{C}$ for $1 \mathrm{~min}$, and the final extension step at 
$72^{\circ} \mathrm{C}$ for $10 \mathrm{~min}$. PCR products were then examined for clarity and intensity. A constant amount of the amplified products $(10 \mu \mathrm{L})$ was electrophoresed in $1.5 \%$ agarose gel and observed usinggel documentation system.

\section{Sequencing}

The PCR products were purified using AccuPrep® PCR Purification Kit (Bioneer, Korea) and sequenced for confidence by Macrogen, Korea. The same primers as for the original PCR were used.

\section{Results \\ Quantity and quality of extracted DNA \\ In this study eleven plasmid extraction protocols were evaluated. Plasmids were extracted and purified from a recombinant $L$. casei strain and estimated spectrophotometrically. Results revealed that the total amount of extracted plasmids differed for each protocol, as confirmed by the PCR amplification of the cloned gene (Fig. 1).}

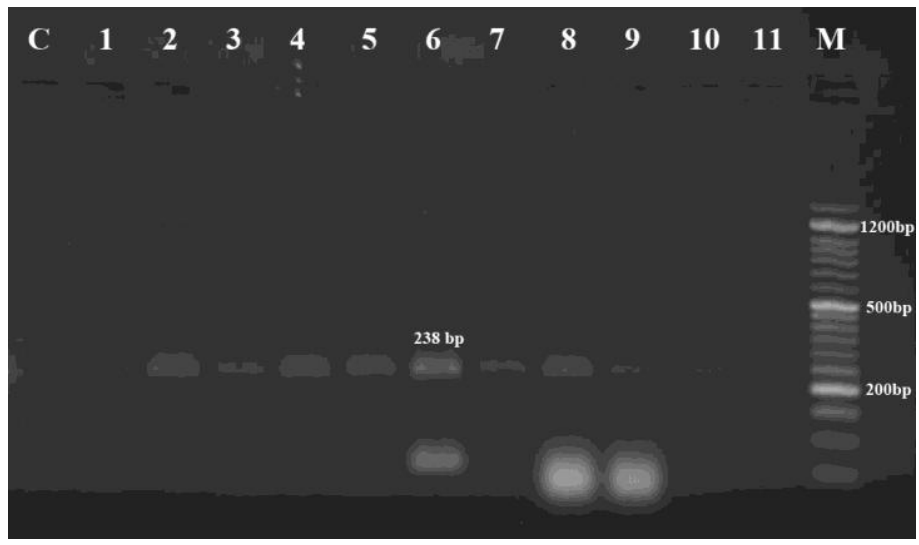


Fig 1: Amplified PCR products ( $10 \mu \mathrm{L}$ of each sample) with the primer set epsilon toxin gene on the extracted plasmid DNA. Lanes 1-11: Amplicons (238 bp) from the eleven plasmid extraction protocols; Lane M: 50 bp DNA markers (Fermentas). Lane C: Negative control (PCR on wild type L.casei)

The agarose gel electrophoresis of the extracted plasmids showed better results for the P6 and $P 7$ protocols in terms of both concentration and purity. In some of the tested protocols (P1 and P11), it was not possible to visualize the plasmid. In comparison with the conventional protocols, using the kit-based and combined protocols resulted in lower total amount of the extracted plasmids (Table 2).

Table 2: Concentration and quality of the extracted plasmids from L. casei by different protocols

\begin{tabular}{cccccccccccc}
\hline & \multicolumn{4}{c}{ KIT based protocols } & \multicolumn{4}{c}{ Conventional protocols } & \multicolumn{3}{c}{ Combined } \\
Protocols & $\boldsymbol{P 1}$ & $\boldsymbol{P 2}$ & $\boldsymbol{P 3}$ & $\boldsymbol{P 4}$ & $\boldsymbol{P 5}$ & $\boldsymbol{P 6}$ & $\boldsymbol{P 7}$ & $\boldsymbol{P 8}$ & $\boldsymbol{P 9}$ & $\boldsymbol{P 1 0}$ & $\boldsymbol{P 1 1}$ \\
\hline $\begin{array}{c}\text { Plasmid Concentration } \\
\text { (ng/ } \mathbf{\mu l})\end{array}$ & 18 & 16 & 44 & 42 & 46 & 116 & 73 & 1041 & 1160 & 48 & 56 \\
$\begin{array}{c}\text { Quality of Plasmid } \\
\left(\mathrm{A}_{260} / \mathrm{A}_{280} \text { ratio) }\right.\end{array}$ & 1.55 & 2.25 & 1.90 & 1.98 & 2.00 & 1.69 & 1.72 & 2.06 & 2.01 & 1.76 & 2.52 \\
\hline
\end{tabular}

\section{PCR amplification of DNA}

All the protocols, except $P 1$, provided acceptable plasmids for PCR amplification with the pair of the used primers. In these protocols, the single band of $238 \mathrm{bp}$ of the target cloned gene was amplified and visualized in agarose gel (Fig.1); however, the resolution of amplicons was different for each protocol. 


\section{Sequencing}

The results of sequencing showed the validity of the target gene (Fig.2).

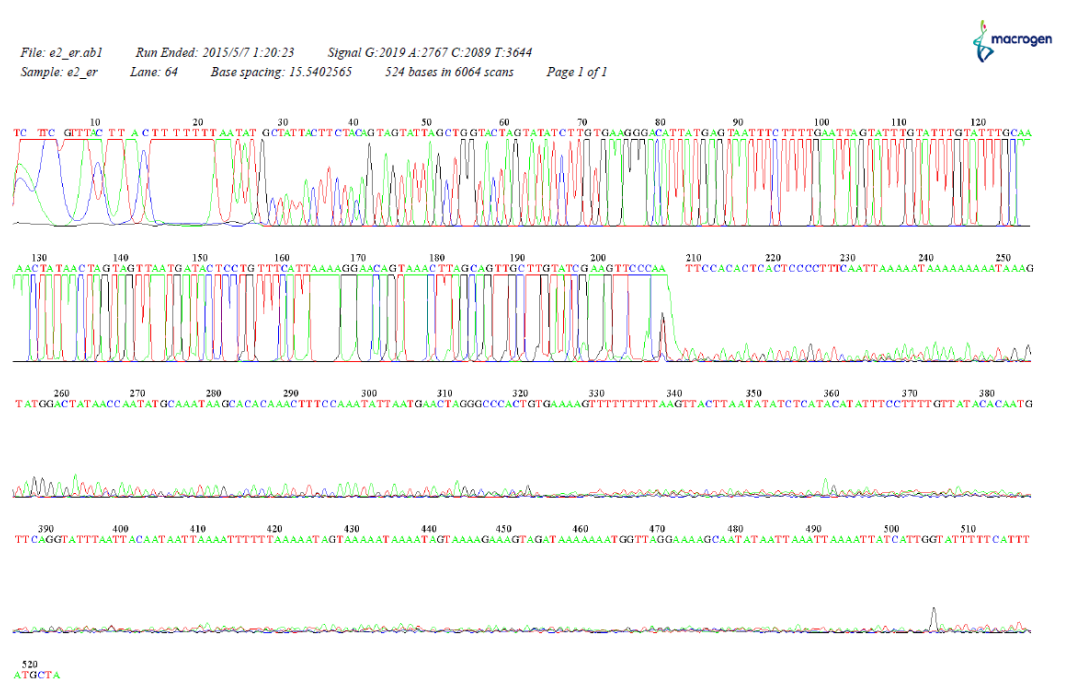

Fig. 2: Sequencing analysis for PCR product. Sequencing chromatogram of an exemplary $238 \mathrm{bp}$ amplicon purified by PCR purification kit.

\section{Discussion}

The application of reproducible and efficient strategies to extract plasmid DNA is essential in molecular biology analyses $[15,16]$. This study evaluated different methods to find the most efficient, economic, and performable way associated with the adequate purity of the extracted plasmid DNA from a recombinant $L$.casei for downstream molecular assays.

Previous studies have been done to evaluate the effectiveness of different plasmid extraction methods from $L$. casei [16-19] but, an efficient and economic method is still required for recombinant $L$. casei strains. Thus, different protocols were tested here.

Formerly, it has been shown that there are some flaws in Lactobacillus spp cell lysis to extract plasmids [10]. These inabilities to extract plasmids prevent further studies of natural 
or recombinant plasmids in this genus. For $L$. casei, it is more critical because of inefficient and time-consuming procedures of cellular lysis due to its specific physiological and morphological characteristics. This difficulty in plasmid extraction may be associated with lysozyme insensitivity $[11,18,20]$. To overcome this, the application of a $37^{\circ} \mathrm{C}$ incubation step for $1 \mathrm{~h}$ can facilitate cell wall digestion by lysozyme [9-11, 14, 20-24]. We tested this in different protocols and the P6 protocol showed a better performance. Longer lysozyme treatment was not recommended because it allows the endogenous nucleases to become active [23].

Our findings indicated that the application of the conventional protocols resulted in better extraction of plasmids from recombinant $L$. casei strains than the other tested protocols. The concentration of the extracted plasmid DNA was significantly higher in the conventional protocols (range: 73-1160 ng/ $\mu$ l) than in the kit-based procedures (range: 16$46 \mathrm{ng} / \mu \mathrm{l}$ ) or combined protocols (range: $48-56 \mathrm{ng} / \mu \mathrm{l}$ ). The highest yield of plasmid DNA was extracted from the $P 9$ protocol as a conventional method $(1160 \mathrm{ng} / \mu \mathrm{l})$. This may be related to lysozyme concentration $(40 \mathrm{mg} / \mathrm{ml})$ and incubation period on ice for 2 hours. Another key issue is the quality of the extracted plasmids from bacterial isolates that affects the sensitivity and usefulness of biological analyses such as PCR [16]. This study showed that different protocols resulted in variable sensitivity of PCR detection. Also, the purity of the extracted plasmid DNA varied from 1.55 to 2.52 in different protocols. In the $P 1$ protocol, the lowest quality product was obtained $\left(\mathrm{A}_{260 /} \mathrm{A}_{280}=1.55\right)$. Moreover, a low molecular band was seen in the amplified PCR products of $P 6, P 8$, and $P 9$ protocols (Fig. 
1) which contributed to their $A_{260} / A_{280}$ ratios (Table 2). This may be related to the high concentration of lysozyme or composition of lysis solution used in these protocols.

In conclusion, the comparison of different extraction protocols showed that the $P 6$ protocol could be the best method (compared with other protocols) for the efficient extraction of plasmid DNAfrom difficult-to-lyse gram positive bacteria such as recombinant $L$. casei strains, which resulted in superior downstream performance in PCR. This method could be used for many purposes such as screening of recombinant colonies after transformation.

\section{Acknowledgements}

Mehdi Golchin supervised the project, entire experiments and manuscript writing. Mojtaba Alimolaei performed the experiments and data analysis and wrote the manuscript. This work was supported by a grant from Iran National Science Foundation(INSF)under grant number 920238680 .

\section{References}

1. Lonkar, P., et al., Isolation, in vitro antibacterial activity, bacterial sensitivity and plasmid profile of Lactobacilli. Asian-australasian journal of animal sciences, 2005. 18(9): p. 13361342.

2. Ali, A.A., Beneficial Role of Lactic Acid Bacteria in Food Preservation and Human Health: A Review. Research journal of microbiology, 2010. 5(12): p. 1213-1221.

3. Soomro, A.H. and T. Masud, Protein pattern and plasmid profile of lactic acid bacteria isolated from dahi, a traditional fermented milk product of Pakistan. Food Technology and Biotechnology, 2007. 45(4): p. 447.

4. Song, B.-f., et al., Chromosomal Insertions in the Lactobacillus casei upp Gene That Are Useful for Vaccine Expression. Applied and environmental microbiology, 2014. 80(11): p. 3321-3326.

5. Cords, B., L. McKay, and P. Guerry, Extrachromosomal elements in group N streptococci. Journal of bacteriology, 1974. 117(3): p. 1149-1152.

6. Gasson, M., F. Davies, and B. Law, The genetics of dairy lactic-acid bacteria. Advances in the microbiology and biochemistry of cheese and fermented milk, 1984: p. 99-126.

7. Klaenhammer, T.R., Plasmid-directed mechanisms for bacteriophage defense in lactic streptococci. FEMS Microbiology Letters, 1987. 46(3): p. 313-325. 
8. McKay, L.L., Functional properties of plasmids in lactic streptococci. Antonie van Leeuwenhoek, 1983. 49(3): p. 259-274.

9. O'sullivan, D.J. and T.R. Klaenhammer, Rapid mini-prep isolation of high-quality plasmid DNA from Lactococcus and Lactobacillus spp. Applied and environmental microbiology, 1993. 59(8): p. 2730-2733.

10. Klaenhammer, T.R., A general method for plasmid isolation in lactobacilli. Current Microbiology, 1984. 10(1): p. 23-28.

11. Cataloluk, O., The development of a modified method for isolating plasmids from exopolysaccharide producing lactobacillus species using conventional plasmid isolation methods. Turk J Biol, 2003. 27: p. 125-129.

12. Alimolaei, M., M. Golchin, and H. Daneshvar, Oral immunization of mice against Clostridium perfringens epsilon toxin with a Lactobacillus casei vector vaccine expressing epsilon toxoid. Infection, Genetics and Evolution, 2016. 40: p. 282-287.

13. Sambrook, J., E.F. Fritsch, and T. Maniatis, Molecular cloning. Vol. 2. 1989: Cold spring harbor laboratory press New York.

14. Anderson, D.G. and L.L. Mckay, Simple and rapid method for isolating large plasmid DNA from lactic streptococci. Applied and environmental microbiology, 1983. 46(3): p. 549-552.

15. Leite, D., et al., Comparison of DNA extraction protocols for microbial communities from soil treated with biochar. Brazilian Journal of Microbiology, 2014. 45(1): p. 175-183.

16. Abed, T.A., Evaluation of methods for the extraction and purification of DNA of cultured Lactobacillus colony isolated from dairy products. 2013.

17. Abdulla, A.A., Optimization of DNA Extraction of Lactobacillus spp for Identification by tuf B gene-Based Polymerase Chain Reaction. Journal of Biology, Agriculture and Healthcare, 2014. 4(8): p. 122-126.

18. De, S., et al., A Simple Method for the Efficient Isolation of Genomic DNA from Lactobacilli Isolated from Traditional Indian Fermented Milk (dahi). Indian journal of microbiology, 2010. 50(4): p. 412-418.

19. Scornec, H., et al., Rapid 96-well plates DNA extraction and sequencing procedures to identify genome-wide transposon insertion sites in a difficult to lyse bacterium: Lactobacillus casei. Journal of microbiological methods, 2014. 106: p. 78-82.

20. Neujahr, H.Y., B. Börstad, and I.-M. Logardt, Factors affecting the resistance of Lactobacillus fermenti to lysozyme. Journal of bacteriology, 1973. 116(2): p. 694-698.

21. Klaenhammer, T., L. McKay, and K. Baldwin, Improved lysis of group $N$ streptococci for isolation and rapid characterization of plasmid deoxyribonucleic acid. Applied and environmental microbiology, 1978. 35(3): p. 592-600.

22. Kado, C., amp, and S. Liu, Rapid procedure for detection and isolation of large and small plasmids. Journal of bacteriology, 1981. 145(3): p. 1365-1373.

23. Ledeboer, A., et al., On the isolation of TI-plasmid from Agrobacterium tumefaciens. Nucleic acids research, 1976. 3(2): p. 449-464.

24. Bimboim, H. and J. Doly, A rapid alkaline extraction procedure for screening recombinant plasmid DNA. Nucleic acids research, 1979. 7(6): p. 1513-1523. 